\title{
Soil taxonomy proposals for acid sulfate soils and subaqueous soils raised by the 8 th International Acid Sulfate Soils Conference
}

Barret M Wessel, John M Galbraith, Mark H Stolt, Martin C Rabenhorst, Delvin S Fanning \& Maxine J Levin

To cite this article: Barret M Wessel, John M Galbraith, Mark H Stolt, Martin C Rabenhorst, Delvin S Fanning \& Maxine J Levin (2017): Soil taxonomy proposals for acid sulfate soils and subaqueous soils raised by the 8th International Acid Sulfate Soils Conference, South African Journal of Plant and Soil, DOI: $10.1080 / 02571862.2017 .1387820$

To link to this article: https://doi.org/10.1080/02571862.2017.1387820

Published online: 11 Dec 2017.

Submit your article to this journal $\sqsubset$

山 Article views: 8

Q View related articles $\square$

View Crossmark data $\longleftarrow$ 


\title{
Soil taxonomy proposals for acid sulfate soils and subaqueous soils raised by the 8th International Acid Sulfate Soils Conference $\$$
}

\author{
Barret M Wessel $^{1 *}$ (D), John M Galbraith ${ }^{2}$ D, Mark H Stolt ${ }^{3}$, Martin C Rabenhorst ${ }^{1}$, Delvin S Fanning ${ }^{1}$ and Maxine \\ J Levin ${ }^{4}$ \\ ${ }^{1}$ Department of Environmental Science and Technology, University of Maryland, College Park, MD 20740, USA \\ 2 Department of Crop and Soil Environmental Sciences, Virginia Polytechnic Institute and State University, Blacksburg, \\ VA 24061, USA \\ ${ }^{3}$ Department of Natural Resources Science, University of Rhode Island, Kingston, RI 02881, USA \\ ${ }^{4}$ USDA-Natural Resources Conservation Service, Beltsville, MD 20705, USA \\ *Corresponding author, email: bwessel@umd.edu
}

\begin{abstract}
The 8th International Acid Sulfate Soils Conference presented examples and discussions for classification of 'acid sulfate soils' and related issues for 'subaqueous soils'. When these soils are disturbed or exposed, the sulfides (predominantly pyrite) react with oxygen to produce sulfuric acid; soil materials that do this to a great extent are recognised as 'sulfidic materials' in Soil Taxonomy. Soil Taxonomy describes physical and chemical properties and thresholds for incubation of sulfidic materials for acidification, and has developed definitions for features and materials commonly seen in these soils. However, based on discussions and examples from field tours the conference has several proposals to modify and add to existing definitions, such as adding new subgroups, defining sulfuric materials and editing the definition of the sulfuric horizon. These changes are centred on improving the interpretative value of taxa in Soil Taxonomy as well as use and management recommendations and their value in soil survey products.
\end{abstract}

Keywords: acid sulfate soils, coastal systems, soil classification, soil taxonomy, subaqueous soils

Acid sulfate (AS) soils include "all soils in which sulfuric acid may be produced, is being produced, or has been produced in amounts that have a lasting effect on main soil characteristics" (Pons 1973). 'Potential' and 'active' AS soils contain sulfide minerals (e.g. pyrite) that can oxidise and produce sulfuric acid if these soils are disturbed or exposed, ruining ecosystems and infrastructure (Fanning et al. 2010, 2017). Subaqueous soils (SAS) are soils that are permanently or nearly-permanently submerged (Soil Survey Staff 2014). Many marine SAS are also AS soils due to the sulfate source in seawater (Fanning and Burch 2000). The description and classification of AS soils and SAS is a developing topic within soil science, spearheaded by eight international meetings over the past several decades (Fanning et al. 2017). The first of these led to the creation of the Acid Sulfate Soils Working Group of the International Union of Soil Sciences. This paper is a summary report of the findings and discussions at the most recent meeting of the Working Group, the 8th International Acid Sulfate Soils Conference (8th IASSC), held in College Park, Maryland, USA, from 17-22 July 2016. These findings were shared with the international soil classification community at the 5th International Soil Classification Congress, held in Bloemfontein, South Africa from 5-7 December 2016. Proposed criteria for Soil Taxonomy (ST) (Soil Survey Staff 2014) and discrepancies with the World Reference Base for Soil Resources (WRB) (FAO 2015) and the Australian Soil Classification (ASC) (Isbell et al. 2016) are offered, with suggestions for further research.

Soil Taxonomy recognises 'sulfidic materials' as sulfidecontaining soil materials that can produce net acidity if disturbed and allowed to oxidise. These are evaluated by monitoring $\mathrm{pH}$ change during moist aerobic incubation (MAI) over a 16-week period (Soil Survey Staff 2014). Sulfidic materials have a pH greater than 3.5 and undergo a $\mathrm{pH}$ decrease of 0.5 or more $\mathrm{pH}$ units to a final $\mathrm{pH}$ of less than 4.0 during MAI. The WRB and ASC (using similar pH thresholds) recognise these as 'hypersulfidic materials', also recognizing 'hyposulfidic materials' as those that acidify to a final $\mathrm{pH}$ above 4.0. The ASC further recognises soil materials that contain metastable Fe sulfides, which change colour from black to grey after several minutes of oxidation, as 'monosulfidic materials'. Soil Taxonomy should recognise these three types of materials. Recent

$\S$ This article is based on a paper presented at the 5th International Soil Classification Congress, 5-7 December 2016, Bloemfontein, South Africa 
papers provide in-depth discussion of these proposals (Payne and Stolt 2017; Wessel and Rabenhorst 2017).

Soil horizons that have acidified as a result of sulfide oxidation are recognised in ST as 'sulfuric horizons'. Sulfuric horizons have a pH of 3.5 or less (4.0 or less if unoxidised sulfide minerals are present). They show evidence that the $\mathrm{pH}$ is caused by production of sulfuric acid - by containing jarosite or similar minerals, $0.05 \%$ or more water-soluble sulfate, or underlying sulfidic materials. Sulfuric horizons must be at least $15 \mathrm{~cm}$ thick, a common thickness for major diagnostic horizons (Fanning and Witty 1993). Thinner horizons that contain sulfuric materials are not identified in a way that reflects their extreme acidity and impact to plant growth and soil chemistry. Sulfuric materials are described in the definition of the sulfuric horizon, but should be defined separately (as sulfidic materials are). Soil Taxonomy should define sulfuric materials with no thickness requirement and edit the definition for the sulfuric horizon to be a horizon that consists of at least $15 \mathrm{~cm}$ of sulfuric materials. This would allow the recognition of sulfuric materials (thinner than $15 \mathrm{~cm}$ ) at the subgroup level.

Subaqueous soils presently fall into two ST suborders: Wassists and Wassents. Surveys of SAS have discovered soils that do not fit within these suborders (Bakken 2012). The ST definition of 'buried soils' requires at least $50 \mathrm{~cm}$ of overlying mantle of new material, so submerged subaerial features can cause soils to key out in orders before the Entisols if the mantle is absent or thinner than $50 \mathrm{~cm}$ (Soil Survey Staff 2014). Examples in the USA include submerged argillic (Erich and Drohan 2012) and spodic (Ellis 2006) horizons. In Australia, some SAS contain sulfuric horizons formed during exposure by extreme drought. These soils key out as Inceptisols in ST, and a Wassept suborder has been proposed (Creeper et al. 2015). However, recent changes to ST exclude SAS from Inceptisols using several lines of reasoning. First, the critical characteristic of this type of soil is that it is permanently underwater. By classifying these soils as Inceptisols, emphasis would be placed on the diagnostic horizons. In many cases the diagnostic horizon that supports Inceptisol instead of Entisol classification did not form in the current soil environment, nor does it affect major interpretations. Another reason to exclude SAS from orders other than Histosols and Entisols is the movement to simplify ST by making fundamental changes (Stolt and Needelman 2015). Allowing SAS with shallow to buried diagnostic horizons to classify as Wassepts (or Wassults, Wassods, etc.) would increase the complexity of ST. New suborders would need additional great groups and subgroups, expanding the number of taxa. One solution would be to add Sulfuric subgroups to the great groups of Wassents (i.e. Sulfuric Haplowassents). Another would be to create a new wet soil order that includes all wet mineral soils including SAS.

One Typic Sulfudept showcased at the 8th IASSC contained a sulfuric horizon, hypersulfidic materials, and a duripan-like layer. This layer did not meet the definition of a duripan because the silica-cementation was so extensive that fragments would not slake. The ST slaking requirement for duripans may be too restrictive; if it were removed a new subgroup would be required for Duric Sulfudepts. Given that it occurs at the soil surface in places, and duripans are subsurface horizons, we recommend that ST recognise 'duricrusts' as the surface expression of these features, as the ASC does. A recent paper describes this soil in detail (Wessel et al. 2017).

During discussions about testing dredged materials for contaminants (Koropchak et al. 2016), it became clear that mapping contamination in SAS could be useful to dredgers. Aside from the description of contaminants as 'particulate artifacts' in soils, ST lacks definitions and language to describe contaminated soils (though Human-Altered and Human-Transported family classes have been established to otherwise describe soils that may pose potential health hazards to humans) (Soil Survey Staff 2014). The WRB describes these soils using the 'toxic' supplementary qualifier (Rossiter 2007). The recognition of contaminated soils should be considered by the National Cooperative Soil Survey (NCSS). Challenges include developing a better understanding of the toxins found in contaminated soils and the dangers they pose, determining with what certainty they can be mapped, and dealing with legal and economic issues associated with identifying land as being 'toxic'. In the short term, Superfund sites and other documented contaminated sites could be marked by a map unit boundary or spot symbol and identified as 'potentially hazardous areas'.

In summary, improvements to ST can be proposed that align it with WRB and ASC definitions and criteria regarding AS soils and diagnostic characteristics. New taxa and definitions are needed in ST for silica-cementation and SAS containing sulfidic and sulfuric materials. Finally, recognition of potential hazards from dredging contaminated material could be incorporated into the NCSS system for mapping purposes.

\section{ORCID}

Barret Wessel (DD https://orcid.org/0000-0001-6264-5734 John Galbraith (iD https://orcid.org/0000-0003-4097-366X Martin Rabenhorst (D) https://orcid.org/0000-0002-1664-7242

\section{References}

Bakken JM. 2012. Soil survey investigations of freshwater subaqueous soils. MSc thesis, University of Rhode Island, Kingston, USA.

Creeper NL, Shand P, Hicks W, Fitzpatrick RW. 2015. Porewater geochemistry of inland acid sulfate soils with sulfuric horizons following postdrought reflooding with freshwater. Journal of Environmental Quality 44: 989-1000.

Ellis LR. 2006. Subaqueous pedology: expanding soil science to near-shore subtropical marine habitats. PhD thesis, University of Florida, Gainsville, USA.

Erich E, Drohan PJ. 2012. Genesis of freshwater subaqueous soils following flooding of a subaerial landscape. Geoderma 179: 53-62.

Fanning DS, Burch SN. 2000. Coastal acid sulfate soils. In: Barnhisel RI, Darmody RG, Daniels WL (eds), Reclamation of drastically disturbed lands. Madison: American Society of Agronomy. pp 921-937.

Fanning DS, Rabenhorst MC, Balduff DM, Wagner DP, Orr RS, Zurheide PK. 2010. An acid sulfate perspective on landscape/ seascape soil mineralogy in the US Mid-Atlantic region. Geoderma 154: 457-464. 
Fanning DS, Rabenhorst MC, Fitzpatrick RW. 2017. Historical developments in the understanding of acid sulfate soils. Geoderma 308: 191-206.

Fanning DS, Witty JE. 1993. Revisions of soil taxonomy for acid sulphate soils. In: van Mensvoort MEF, Dent DL (eds), Selected papers of the Ho Chi Minh City Symposium on Acid Sulphate Soils, Ho Chi Minh City, Vietnam, March 1992. ILRI Publication 53. Wageningen: International Institute for Land Reclamation and Improvement. pp 61-69.

FAO (Food and Agriculture Organization of the United Nations). 2015. World reference base for soil resources 2014. World Soil Resources Reports 106. Rome: FAO.

Isbell RF, National Committee on Soil and Terrain. 2016. The Australian soil classification (2nd edn). Australian soil and land survey handbooks series. Clayton: CSIRO Publishing.

Koropchak SC, Daniels WL, Wick A, Whittecar GR, Haus N. 2016. Beneficial use of dredge materials for soil reconstruction and development of dredge screening protocols. Journal of Environmental Quality 45: 62-73.

Payne MK, Stolt MH. 2017. Understanding sulfide distribution in subaqueous soil systems in southern New England, USA. Geoderma 308: 207-214.
Pons LJ. 1973. Outline of the genesis, characteristics, classification and improvement of acid sulphate soils. In: Dost $\mathrm{H}$ (ed.), Proceedings of the International Symposium on Acid Sulphate Soils, 13-20 August 1972, Wageningen, The Netherlands. ILRI Publication 18. Wageningen: International Institute for Land Reclamation and Improvement. pp 3-27.

Rossiter DG. 2007. Classification of urban and industrial soils in the World Reference Base for Soil Resources. Journal of Soils and Sediments 7: 96-100.

Soil Survey Staff. 2014. Keys to soil taxonomy (12th edn). Washington, DC: USDA-Natural Resources Conservation Service.

Stolt $\mathrm{MH}$, Needelman BA. 2015. Fundamental changes in soil taxonomy. Soil Science Society of America Journal 79: 1001-1007.

Wessel BM, Fiola JC, Rabenhorst MC. 2017. Soil morphology, genesis, and monolith construction of an acid sulfate soil with silica-cementation in the US Mid-Atlantic Region. Geoderma 308: 260-269.

Wessel BM, Rabenhorst MC. 2017. Identification of sulfidic materials in the Rhode River subestuary of Chesapeake Bay. Geoderma 308: 215-225. 
